\title{
Landscape Analysis for PaV1 Infection in Lobsters Panulirus argus from the Artisanal Fishery of the Eastern Coast of Yucatan, Mexico
}

\author{
Ruth A. Pérez-Campos ${ }^{1}$, Oswaldo Huchim-Lara ${ }^{2}$, Silvia Salas ${ }^{2}$, \\ María Liceaga-Correa ${ }^{3}$, Héctor Hernández-Nuñez ${ }^{3}$, \\ Cristina Pascual-Jiménez ${ }^{4}$, Rossanna Rodríguez-Canul ${ }^{*}$ \\ ${ }^{1}$ Laboratorio de Inmunología y Biología Molecular, Mérida, Yucatán, México \\ ${ }^{2}$ Laboratorio de Pesquerías, Mérida, Yucatán, México \\ ${ }^{3}$ Laboratorio de Percepción Remota y Sistemas de Información Geográfica, Centro de Investigación y de \\ Estudios Avanzados del IPN-Mérida (CINVESTAV-IPN), Merida, Mexico \\ ${ }^{4}$ Universidad Nacional Autónoma de México, Facultad de Ciencias, Unidad Académica Sisal, Sisal, Mexico \\ Email: *rossana@mda.cinvestav.mx, "Rossana.rodriguez@cinvestav.mx
}

Received 29 April 2016; accepted 5 July 2016; published 8 July 2016

Copyright (C) 2016 by authors and Scientific Research Publishing Inc.

This work is licensed under the Creative Commons Attribution International License (CC BY).

http://creativecommons.org/licenses/by/4.0/

c) (i) Open Access

\begin{abstract}
Panulirus argus virus 1 (PaV1) is considered a major threat to spiny lobsters Panulirus argus. In this study Geospatial analysis was used to analyze PaV1 distribution in an artisanal fishery of spiny lobster Panulirus argus population from the north coast of the Yucatan Peninsula. Adult and sub-adult $P$. argus and seabed coverage data were collected from thirty artisanal fishing sites. Five seabed coverage types were identified: seagrass; sand/seagrass mixture; sand only; coral/sand mixture; and seaweed. No juveniles were examined. Of the 358 collected lobsters, PaV1 was identified in four organisms (three sub-adults and one adult) from two fishing sites (termed A \& B), both found in a seagrass coverage area. Overall prevalence was of $1.12 \%$. Prevalence was of $20 \%$ $(2 / 10)$ at one site and of $12.6 \%(2 / 16)$ at the other.
\end{abstract}

\section{Keywords}

Panulirus argus, PaV1, Geospatial Analysis, Artisanal Fishery, Seagrass

"Corresponding author.

How to cite this paper: Pérez-Campos, R.A., et al. (2016) Landscape Analysis for PaV1 Infection in Lobsters Panulirus argus from the Artisanal Fishery of the Eastern Coast of Yucatan, Mexico. Open Journal of Marine Science, 6, 386-394. 


\section{Introduction}

The Caribbean spiny lobster (Panulirus argus) (Latreille, 1804) supports an important economically valuable fishery in the Caribbean [1] [2]. Spiny lobster P. argus has a lengthy (5 to 9 months) planktonic larval phase comprising 10 stages, called phyllosomata (singular: phyllosoma). This is followed by metamorphosis into a swimming, non-feeding postlarval stage (puerulus) [3], which occurs in oceanic waters beyond the shelf break [4]. Postlarvae actively swim towards coastal areas to settle in shallow benthic habitats of macroalgae and seagrass. Once settled, the puerulus molts into the first juvenile stage. Juvenile lobsters remain in settlement habitats for a few months before shifting to crevice-type shelters [5].

In particular, $P$. argus constitutes a commercially important artisanal fishery in the northeast coast of Yucatan state, Mexico [6] [7]. Legal sized organisms are collected by local fishermen from the port towns of San Felipe and Rio Lagartos, Yucatán by "hookah", a method of diving in which the diver gets air from a plastic tube that is attached to a compressor placed in the central part of the boat [8]. Collected lobsters are confined in "cooperatives" were commodities are then exported worldwide. It has been reported that stocks of $P$. argus are overexploited or nearly so in many areas of the Caribbean [9], and the loss of spawning stock may explain the general decline in many fisheries [10]. However, the discovery of the pathogenic virus Panulirus argus Virus 1 (PaV1) [11], is becoming a major concern, because it could affect negatively $P$. argus fisheries; this double stranded DNA virus causes a progressive and detrimental infection that ends in death of juvenile lobsters. In experimental infections with $P$. argus juveniles, PaV1 infected lobsters show lethargy, morbidity, "milky" hemolymph, lack of hemolymph coagulation, and suppression of molt in a range of 30 to 80 days post infection [12]. In the field, PaV1 infected lobsters are recognized by local fishermen as "milky lobsters". PaV1 is more prevalent in juveniles. This prevalence decreases in sub-adults and adults and clinical signs characteristic of PaV1 are difficult to evaluate in the field [12]. PaV1 is highly prevalent throughout the Caribbean region and its propagation could impact $P$. argus fisheries [2] [10] [12]-[15].

The fishing area comprised by the port towns of Rio Lagartos and San Felipe contributes with approximately $30 \%$ of the total lobster catch in the waters of the Yucatan Peninsula [16]. In that area artisanal lobster fisheries based in these communities target habitats hosting large populations of juvenile and sub-adult lobsters [17]. A decline in $P$. argus landings have been documented since the last decade [17]. There is no record of PaV1 in this artisanal fishery and the use of Remote sensing (RS) that encompasses a variety of geospatial analysis techniques that largely use satellite images can help in the identification of potential factors contributing to PaV1 occurrence that would account for spatial congruity of neighboring infected sites [18]-[21].

The present study objective was to identify PaV1 infection prevalence in adults and sub-adults in the artisanal lobster fishery of two main port towns of the Yucatan Peninsula, and to use remote sensing technology to evaluate how marine habitats potentially affect the host-pathogen association in this sub-population of $P$. argus.

\section{Material and Methods}

\subsection{Study Area}

The study area included the coastal seabed north of the port towns of Rio Lagartos ( $\left.21^{\circ} 35^{\prime} 51^{\prime \prime} \mathrm{N}, 88^{\circ} 09^{\prime} 28^{\prime \prime} \mathrm{W}\right)$ and San Felipe $\left(21^{\circ} 34^{\prime} 0^{\prime \prime} \mathrm{N}, 88^{\circ} 13^{\prime} 0^{\prime \prime} \mathrm{W}\right)$ on the northeast coast of Yucatan state, Mexico (Figure 1). Rio Lagartos is a coastal lagoon covering approximately 9467 ha ( $\sim 80 \mathrm{~km}$ long $\times 25 \mathrm{~m}-3.5 \mathrm{~km}$ wide), that is bordered by mangroves and covered by seagrass bed zones (Halodule wrightii). It is connected to the sea by a natural inlet in front of the town of San Felipe and an artificial canal in front of the town of Rio Lagartos. Both towns' local economies depend heavily on the artisanal lobster fishery [22].

Habitat structure in the study area has been classified ashard bottom, locally known as coquina. It consists of sedimentary carbonate rock composed almost entirely of fragments of mollusk, trilobite and other invertebrate shells that have been transported, eroded and mechanically dispersed bycurrents and waves [16]. Seabed coverage is a combination of seagrass (Thallassiatestudinum and Syringodium filiforme) and sandy areas close to shore, with long flat rocky ridges further offshore. These are riddled with cavities and fissures that provide refuge for lobster and demersal fishes. Area substrate coverage also includes octocorals, stony corals, sponges, and macroalgae (Green, Rhodophyta, Calcareous, Filamentous, Phaeophyceae, and encrusting algae) [17].

\subsection{Sample and Data Collection}

Lobsters were collected by local fishermen during the fishing season of July 2013-july 2014 (with a restricted 


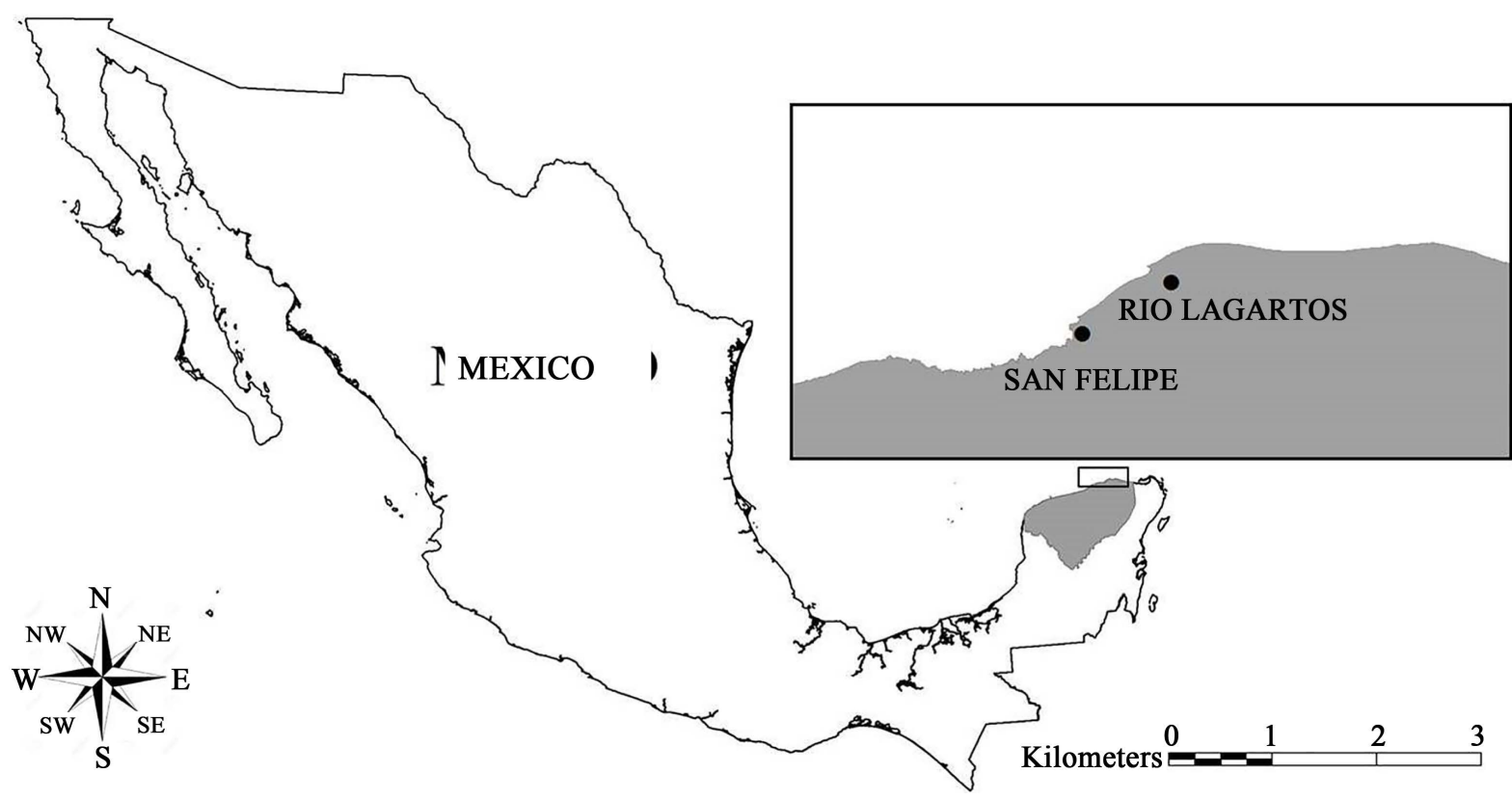

Figure 1. Study sites (ports of San Felipe and Rio Lagartos) off northeast coast of Yucatan state, Mexico (scale: 1 km).

catching season from February up to June). Based on fishermen's nomenclature, the fishing sites were labeled alphabetically from A to AD. All collected lobsters were measured [abdominal length (AL), and carapace length (CL)] and sexed. Soon after sampling, the exoskeleton of each lobster was swabbed with $70 \%$ ethanol, and 300 $\mu \mathrm{l}$ of hemolymph was withdrawn from the base of one of the 5th periopod using a sterile $1 \mathrm{ml}$ disposable syringe fitted with a 30 gauge needle. Hemolymph was immediately fixed in 95\% ethanol (ratio 1:3 v/v), divided into aliquots of $300 \mu \mathrm{l}$ and stored in a cooler containing frozen refrigerant packs until stored at $-80^{\circ} \mathrm{C}$ [23].

\subsection{DNA Extraction, PCR Screening for PaV1 and DNA Sequence}

DNA was extracted from individual samples of hemolymph under a flow cabinet to avoid sample cross-contamination. Briefly, aliquots of $70 \%$ ethanol fixed hemolymph were thawed at ambient temperature for 15 min and centrifuged at $3000 \times \mathrm{g}$ for $1 \mathrm{~min}$. The pellet containing intact hemocytes, cell debris, and clotted serum proteins ( $\sim 30 \mathrm{mg}$ ) was homogenized in $300 \mu \mathrm{l}$ of $10 \%$ Chelex-100 (Sigma-Aldrich) containing $20 \mu \mathrm{lof} 20 \mathrm{mg} \cdot \mathrm{ml}^{-1}$ Proteinase $\mathrm{K}$ by agitation for $10 \mathrm{~s}$ and incubated at $56^{\circ} \mathrm{C}$ for $3 \mathrm{~h}$ and $94^{\circ} \mathrm{C}$ for $10 \mathrm{~min}$. After being centrifuged at $3000 \mathrm{~g}$ for $3 \mathrm{~min}$, a supernatant fluid containing DNA was carefully transferred into a sterile tube and stored at $-20^{\circ} \mathrm{C}$. DNA quality and quantity was confirmed by determining the absorbance ratio A260:A280 using a NanoDrop 2000c spectrophotometer (Thermo-Scientific), and chromosomal DNA integrity was assessed by resolving DNA in 1\% agarose gels [23]. The quality of genomic DNA was assessed by amplifying the small subunit ribosomal RNA (SSU rRNA) of the lobster using “universal” SSU rRNA primers modified from Medlin et al. (1988) [24]. The amplified target DNA fragment was approximately 1800 bp in length according to Moss et al. (2012) [14].

The PCR reaction was run in a $25 \mu \mathrm{l}$ reaction containing $1 \mu \mathrm{l}$ extracted DNA; $0.33 \mu \mathrm{M}$ each of the primers 45aF and 543aR [25]; $2.5 \mathrm{mM} \mathrm{MgCl}_{2}$ (Promega); 0.6X reaction buffer (Promega); $0.4 \mathrm{mM} \mathrm{dNTP} \mathrm{mixture} \mathrm{(Pro-}$ mega); and $0.75 \mathrm{U}$ Taq DNA polymerase (Promega). Thermal cycling conditions were: 1 cycle at $94^{\circ} \mathrm{C}$ for 10 min; 30 cycles at $94^{\circ} \mathrm{C}$ for $30 \mathrm{~s}, 63^{\circ} \mathrm{C}$ for $30 \mathrm{~s}$, and $72^{\circ} \mathrm{C}$ for $1 \mathrm{~min}$; and $72^{\circ} \mathrm{C}$ for $10 \mathrm{~min}$. The presence of the expected 499 bp PaV1 amplicon was determined by dissolving $5 \mu$ l PCR product and $3 \mu \mathrm{l}$ loading buffer in a $2 \%$ agarose gel containing $0.1 \%$ ethidium bromide. Visualization was done using UV illumination (MiniBis Pro ${ }^{\circledR}$ ). The negative control was DNA from uninfected lobsters and ultrapure water, and the positive control was DNA from lobsters heavily infected with PaV1 [23] [25] [26]. The PCR was performed in triplicate to avoid non-specific results.

The PCR products were forward- and reverse-sequenced at the CINVESTAV IPN-Unidad Irapuato. Sequences were checked and aligned using the CLUSTALW option in the MEGA4 software [27]. Similarity in the consensus sequence was searched in the GenBank ${ }^{\mathrm{TM}}$ using the basic local alignment search tool (BLAST) 
(http://blast.ncbi.nlm.nih.gov).

\subsection{Supervised Classification of Seabed Landscape}

Seabed coverage characteristics by video recording and photography were performed in the 30 fishing sites. Site geographic coordinates and seabed data were converted into a decimal format and vectors created for each. Supervised classification was done by adding seabed coverage coordinates as seeds into a multispectral Landsat image, labeling each of the five classes identified during fieldwork. A parametric supervised pixel-by-pixel classification using maximum likelihood was chosen for classification. Probability operations were used to assign each pixel to precisely its class. Finally, an error matrix was implemented to determine overall accuracy. After classification, fishing site coordinates were added to the classified image. A mask was added to differentiate between terrestrial and sea water coverages. Images were created with the TNT Mips and ArcGis software programs.

\subsection{Data Analysis}

Prevalence was calculated as the proportion (\%) of PaV1-positive individuals from each sampling site [28]. The non-parametric Friedman test was applied to identify significant differences $(\alpha<0.05)$ between the proportion of fishing sites and the presence of PaV1-positive lobsters on the different types of seabed coverage [29].

\section{Results}

\subsection{Lobster Samples and Disease Prevalence Distribution}

A total of 358 lobsters were caught: 182 (51\%) male and 176 (49\%) female (Table 1). Mean lobster tail length $(\mathrm{cm})$ was $12.87 \pm 2.72 \mathrm{~cm}$, with a range from 9.1 to $15.5 \mathrm{~cm}$. 56\% $(\mathrm{n}=202)$ were classified as sub-adults (5.1 $8.0 \mathrm{~mm} \mathrm{CL})$ and $44 \%(\mathrm{n}=156)$ were adults $(>8.1 \mathrm{~cm}$ CL) (Table 1$)$. The proportion of less than legal size lobsters to those at/or above legal size was almost 5:1. Most of the small lobsters were caught near to the coast in shallow waters while the larger lobsters were caught in deeper waters further offshore. Mean depth $(\mathrm{m})$ at which specimens were caught was $12.8 \pm 4.9 \mathrm{~m}$, with a range from 4.59 to $21.90 \mathrm{~m}$. Mean seawater temperature $\left({ }^{\circ} \mathrm{C}\right)$ at the time of capture was $23.9^{\circ} \mathrm{C} \pm 1.51^{\circ} \mathrm{C}$, with a range of $21.1^{\circ} \mathrm{C}$ to $25.8^{\circ} \mathrm{C}$.

Four lobsters were PaV1-positive showing a specific 499 bp band; two sub-adults (20\% prevalence) at the sampling site A (12.66 m depth; $25.08^{\circ} \mathrm{C}$ temperature), and one sub-adult and one adult respectively (12.5\% prevalence) at the sampling site B (17.14 m depth; $21.9^{\circ} \mathrm{C}$ temperature) (Table 2). None of the organisms

Table 1. Number of $P$. argus caught (size and sex) by fishing site and seabed coverage type.

\begin{tabular}{cccccccc}
\hline & & & \multicolumn{3}{c}{ Size } & \multicolumn{3}{c}{ Sex } \\
\cline { 5 - 8 } Coverage types & Fishing sites & $\mathrm{N}$ & Adults & Subadults & Male & Female \\
\cline { 5 - 8 } Seagrass & $13(\mathrm{~A}-\mathrm{M})$ & 116 & 35 & 81 & 63 & 53 \\
Sand/seagrass & $10(\mathrm{~N}-\mathrm{W})$ & 63 & 54 & 9 & 34 & 29 \\
Sand & $2(\mathrm{X}, \mathrm{Y})$ & 2 & 2 & 0 & 76 & 54 & 64 \\
Coral/Sand & $3(\mathrm{Z}-\mathrm{AB})$ & 118 & 42 & 36 & 29 & 30 \\
Seaweed & $2(\mathrm{AC}, \mathrm{AD})$ & 59 & 23 & 202 & 182 & 176 \\
TOTAL & 30 & 358 & 156 & & & & \\
\hline
\end{tabular}

Table 2. PaV1 infection in spiny lobster $P$. argus in study area.

\begin{tabular}{|c|c|c|c|c|c|c|c|}
\hline \multirow{2}{*}{ Fishing site } & \multirow{2}{*}{$\begin{array}{c}\text { Lobsters } \\
\text { Caught }\end{array}$} & \multirow{2}{*}{$\begin{array}{l}\text { Infected } \\
\text { Lobsters }\end{array}$} & \multicolumn{2}{|c|}{ Lobster size } & \multirow{2}{*}{$\begin{array}{c}\text { PaV1 } \\
\text { Prevalence }\end{array}$} & \multirow{2}{*}{$\begin{array}{l}\text { Depth } \\
\text { (m) }\end{array}$} & \multirow{2}{*}{ Temperature $\left({ }^{\circ} \mathrm{C}\right)$} \\
\hline & & & Adults & Subadults & & & \\
\hline A & 10 & 2 & 0 & 2 & 20 & 17.14 & 21.90 \\
\hline B & 16 & 2 & 1 & 1 & 12.5 & 12.66 & 25.08 \\
\hline
\end{tabular}


showed evidence of clinical signs of the disease (i.e. milky hemolymph).The four DNA sequences of the positive lobsters showed high coverage and $95 \%$ of similarity to a DNA sequence of 499 bp fragment of PaV1 (GenBank ${ }^{\mathrm{TM}}$ accession no. EF206313.1).

\subsection{Seabed Coverage Types Based on Supervised Classification}

Five seabed coverage types were classified: seagrass; a sand/seagrass mixture; sand only; a coral/sand mixture; and seaweed (Figure 2). A sandy fringe area prevailed near the coast while seagrass and seaweed dominated throughout the lagoon and in small areas near the coast. Beyond the sandy fringe, coverage was a mixture of coral with patches of sand/seaweed. Seagrass was predominant beginning at 30 kilometers from the coast. The classification error matrix indicated accuracy to be $85.21 \%$.

When fishing sites were overlaid onto the supervised classification image, it was clear that most were located in seagrass or sand/seagrass coverage types (Table 1). A small number were located in the sandy coastal fringe, and none was located on seaweed. The non-parametric Friedman analysis identified significant differences between the proportion of fishing sites in seagrass and other coverage types $\left(\mathrm{T}^{2}=4.17 \mathrm{df}=4 ; \mathrm{p}=0.0033\right)$. Significant differences were also present in PaV1 infection prevalence between coverage types $\left(\mathrm{T}^{2}=4.43\right.$, $\mathrm{df}=4 ; \mathrm{p}=$ 0.0022). Of the PaV1-positive sites, Site A is located northeast of the port towns and Site B to the northwest, but both have seagrass coverage (Figure 2).

\section{Discussion}

This is the first report of PaV1 in an artisanal fishery from Southern Mexico, and despite the low prevalence of PaV1, this work provide information about the health status of $P$. argus spiny lobsters from the fishing season of 2013-2014, providing baseline data that can be useful in future evaluations of PaV1 distribution in the area or in areas with similar landscape.

The geospatial analysis used herein was very useful in identifying the natural habitats of $P$. argus [30]. Seagrass was very frequent in the study area. Other studies done in Florida and the Caribbean region report a different scenario, with hard-bottom habitat interspersed with seagrass meadows serving as nurseries and foraging grounds for numerous species of fish and shellfish, including $P$. argus. Seagrass is reported to play an important role in sustaining juvenile lobster populations and in recruitment in adult lobster fisheries [31]. Of the 358 lobsters

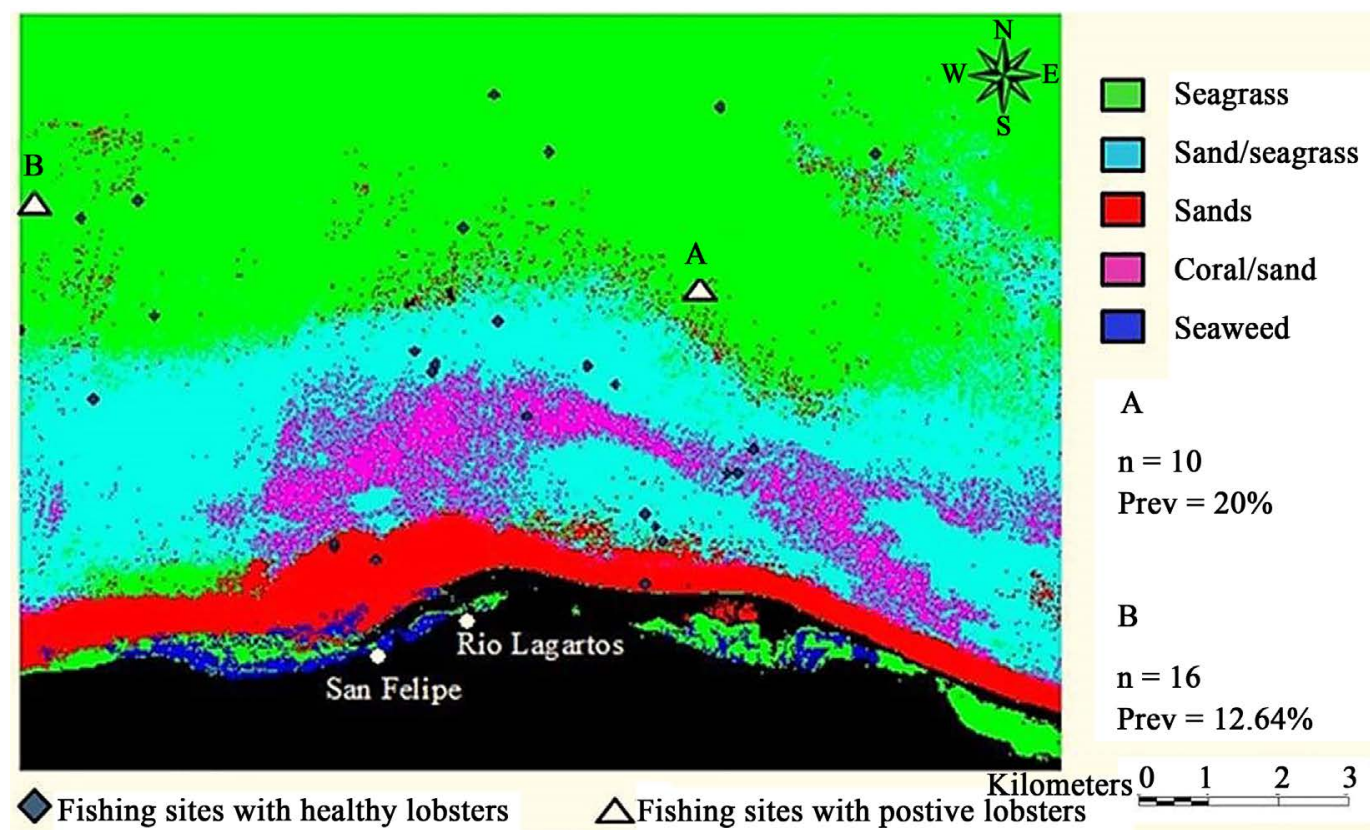

Figure 2. Fishing site locations and seabed coverage types based on a supervised classification. ( $\square$ Seagrass, $\square$ Sand/Seagrass, $\square$ Sand, $\square$ Coral/Sands, $\square$ Seaweed, $\diamond$ Fishing site with healthy lobster, $\Delta$ Fishing site with positive lobsters [A: $n=10$, prevalence $=20 \%$; $: n=16$, prevalence $=12.64 \%$ ). 
tested for PaV1 by PCR, only 3 sub-adults and 1 adult tested positive. Although overall prevalence was extremely low (1.12\%), at the sites where PaV1 was found prevalence ranged from $20 \%$ (site A) to $12.65 \%$ (site B); both have seagrass coverage. These levels are consistent with the $0 \%-15 \%$ reported in other zones of the Caribbean [10] [15] [32] [33].

The Friedman test showed that seagrass beds are not the only bottom coverage with a high number of lobster fishing sites, although most of the study area are covered with seagrass and PaV1-positive lobsters at each of sites A and B were located there. The distribution of PaV1 in the Caribbean region may be via dispersion of larval stages (puerulus) [34]. P. argus pueruli may become infected by contact with floating concentrated masses of Sargassum that function as reservoirs for PaV1 particles in offshore waters [35]. In this sense, the extensive seagrass beds off the coast of San Felipe and Rio Lagartos may be functioning as a PaV1 reservoir. However, more work has to be done to confirm the significance between the PaV1 prevalence and seagrass coverage.

The ubiquity of seagrass in the study area may also be increasing the risk of possible contact between PaV1positive lobsters and non-infected lobsters. In laboratory experiments with juveniles, non-diseased lobsters avoided shelters harboring a diseased lobster at significant rates, both in the absence and presence of predation risk [31]. In the wild, however, many lobsters may not have this option since environmental changes can modify habitats and alter the spatial structure of the lobster population in ways that diminish the effectiveness of social aversion in retarding the spread of PaV1 [36]. In the study area, natural structures providing refuges, such as rocks and caves, are interspersed among areas with vegetation, increasing the risk of gregariousness and PaV1 transmission [35]. Even though prevalence was very low in the area, limited shelter availability can cause lobsters to aggregate. In addition, fishing can alter natural patterns of den co-occupancy that may influence disease transmission, and fishers manipulate the abundance of sub legal-sized lobsters in traps, increasing possible disease transmission [32].

Regarding to the PaV1-PCR; it has been validated previously in diseased spiny lobsters $P$. argus with and without clinical signs of PaV1, and it has been also used to assess PaV1 prevalence in frozen lobsters tails intended for commercialization, thus the risk of non-specificity is very low [23] [26]. The DNA sequence obtained herein, showed a high homology to a similar DNA sequence of PaV1 from the GenBank ${ }^{\mathrm{TM}}$, confirming that the amplified PCR products described here were from DNA of PaV1 infected lobsters. In this sense, it has been reported that lobster surveys based on observed clinical disease has underestimated the prevalence of PaV1 infection, especially in early-stage of subclinical infections because the clinical signs appear as PaV1 infection progresses [23]. For example, in Quintana Roo, Mexico, the prevalence of PaV1 by clinical signs was higher among lobsters at Punta Allen $(8.4 \%, n=1842)$ compared to Vigía Chico $(1.5 \%, n=2016)$ [37]. But in an ongoing research in the same zones in 2013, the PaV1-PCR detected higher prevalence of PaV1 in Punta Allen (28.1\% of 420 lobsters) and in Vigía Chico (3.0\% of 263 lobsters), compared with PaV1 prevalence by clinical signs in the same organisms (15\% and $0.8 \%$, respectively) [26].

Mapping of PaV1 prevalence and incidence in lobsters using global positioning system (GPS) and geographic information system (GIS) technologies may reveal the impact of abiotic and biotic factors influencing PaV1 disease risk [38]. By coupling these technologies with PaV1 disease detection tools such as PCR and survey data, prevalence and incidence maps can be generated that depict well-defined geographical areas with high or low PaV1 risk [40]. Traditional epidemiological models are not very adept at transmission dynamics analysis when complicated by changes in habitat structure or quality, host behavior, or ontogeny that alter disease transmission patterns [36]. Implementing risk maps prior to lobster fishing seasons could facilitate geographic deployment of disease management measures aimed at preventing PaV1 spread into other fishing areas and other populations [38]-[40].

In conclusion, data reported here are preliminary, but can serve as a foundation for more comprehensive research including a lobster census to evaluate how population density and habitat influence PaV1 transmission and distribution in commercial lobster fisheries. The epidemiology of large-scale marine diseases such as PaV1 is an emerging discipline and will probably require analyzes that integrate physical dynamics, anthropogenic influence and disease history to identify potential pathogen sources in the oceans, an approach similar to that applied in terrestrial environments. Its extensive distribution in the Caribbean highlights the need to establish an integrated PaV1 monitoring program including an online database on its behavior over time. The present evaluation of $\mathrm{PaV} 1$ prevalence in a large asymptomatic $P$. argus sub-population at a regional scale emphasizes the need for further study of density effects and how habitat restrictions potentially alter the host-pathogen association. In conclusion, detection of PaV1 in artisanal lobster fisheries through geospatial analyzes provides an additional 
tool to evaluate transmission of the disease in asymptomatic carriers such as adults and sub-adults.

\section{Acknowledgements}

Special thanks are conveyed to local fishermen from San Felipe and Río Lagartos, México for their unconditional support. R. A. P. C. is holding a PhD studentship granted by CONACyT. Financial support was provided by the external services performed at the laboratory of Immunology and Molecular Biology, CINVESTAV IPN Unidad Mérida (reference No. A3329) and grant UNAM PAPIIT IN215113.

\section{References}

[1] Lozano-Alvarez, E., Briones-Fourzán, P., Ramírez-Estévez, A., Placencia-Sánchez, D., Huchin-Mian, J.P. and RodríguezCanul, R. (2008) Prevalence of Panulirus argus Virus 1 (PaV1) and Habitation Patterns of Healthy and Diseased Caribbean Spiny Lobsters in Shelter-Limited Habitats. Disease Aquatic Organisms, 80, 95-104. http://dx.doi.org/10.3354/dao01921

[2] Behringer, D.C., Butler, M.J.I., Shields, J.D. and Moss, J. (2011) Review of Panulirus argus Virus 1-A Decade after Its Discovery. Disease Aquatic Organisms, 94, 153-160. http://dx.doi.org/10.3354/dao02326

[3] Goldstein, J.S., Matsuda, H., Takenouchi, T. and Butler, M.J.I. (2008) A Description of the Complete Development of Larval Caribbean Spiny Lobster Panulirus argus (LATREILLE, 1804) in Culture. Journal of Crustacean Biology, 28, 306-327. http://dx.doi.org/10.1163/20021975-99990376

[4] Phillips, B.F. and McWilliam, P.S. (2009) Spiny Lobster Development: Where Does Successful Metamorphosis to the Puerulus Occur? A Review. Reviews in Fish Biology and Fisheries, 19, 193-215. http://dx.doi.org/10.1007/s11160-008-9099-5

[5] Butler, M.J.I. (1995) Cascading Disturbances in Florida Bay, USA: Cyanobacteria Blooms, Sponge Mortality, and Implications for Juvenile Spiny Lobsters Panulirus argus. Marine Ecology Progress Series, 129, 119-125. http://dx.doi.org/10.3354/meps129119

[6] Rios-Lara, G.V. (2009) Identificación del Hábitat y de los Factores que Determinan la Distribución Espacial de Langosta en la Plataforma de Yucatán: Modelación y Evaluación de la Población Gloria Verónica Ríos Lara. Tesis Doctoral. Centro de Investigación y de Estudios Avanzados del Instituto Politécnico Nacional.

[7] Salas, S., Mexicano-Cíntora, G. and Cabrera, M.A. (2005) ¿Hacia donde van las pesquerías en Yucatán? Tendencias, retos y perspectivas. Centro de Investigación y Estudios Avanzados, Departamento de Recursos del Mar, Unidad Mérida.

[8] Huchim-Lara, O., Salas, S., Chin, W., Montero, J. and Fraga, J. (2015) Diving Behavior and Fishing Performance: The Case of Lobster Artisanal Fishermen of the Yucatan Coast, Mexico. Undersea and Hyperbaric Medicine Journal, 42, 285-296.

[9] Chaves, E.A. (2009) Potential Production of the Caribbean Spiny Lobster (Decapoda, Palinura) Fisheries. Crustaceana, 82, 1393-1412. http://dx.doi.org/10.1163/001121609X12481627024373

[10] Shields, J.D. (2011) Diseases of Spiny Lobsters: A Review. Journal of Invertebrate Pathology, 106, 79-91. http://dx.doi.org/10.1016/j.jip.2010.09.015

[11] Shields, J.D. and Behringer, D.C. (2004) A New Pathogenic Virus in the Caribbean Spiny Lobster Panulirus argus from the Florida Keys. Diseases of Aquatic Organisms, 59, 109-118. http://dx.doi.org/10.3354/dao059109

[12] Huchin-Mian, J.P., Rodríguez-Canul, R., Arias-Bañuelos, E., Simá-Alvarez, R., Pérez-Vega, J.A., Briones-Fourzán, P. and Lozano-Alvarez, E. (2008) Presence of Panulirus argus Virus 1 (PaV1) in Juvenile Spiny Lobsters Panulirus argus from the Caribbean Coast of Mexico. Disease Aquatic Organisms, 79, 153-156. http://dx.doi.org/10.3354/dao01898

[13] Behringer, D.C., Butler, M.J.I. and Shields, J.D. (2008) Ecological and Physiological Effects of PaV1 Infection on the Caribbean Spiny Lobster (Panulirus argus Latreille). Journal of Experimental Marine Biology and Ecology, 359, 2633. http://dx.doi.org/10.1016/j.jembe.2008.02.012

[14] Moss, J., Butler, M.J.I., Behringer, D.C. and Shields, J.D. (2012) Genetic Diversity of the Caribbean Spiny Lobster Virus, Panulirus argus Virus 1 (PaV1), and the Discovery of PaV1 in Lobster Postlarvae. Aquatic Biology, 14, 223232. http://dx.doi.org/10.3354/ab00395

[15] Moss, J., Behringer, D.C., Shields, J.D., Baeza, A., Aguilar-Perera, A., Bush, P.G., Dromer, C., Herrera-Moreno, A., Gittens, L., Matthews, T.R., McCord, M.R., Schärer, M.T., Reynal, L., Truelove, N. and Butler, M.J.I. (2013) Distribution, Prevalence, and Genetic Analysis of Panulirus argus Virus 1 (PaV1) from the Caribbean Sea. Disease Aquatic Organisms, 104, 129-140. http://dx.doi.org/10.3354/dao02589 
[16] Rios-Lara, G.V., Espinoza-Mendez, J.C., Zetina-Moguel, C., Aguilar-Cardozo, C. and Ramírez-Estévez, A. (2013) La pesquería de langosta Panulirus argus en el Golfo de México y mar Caribe mexicano. Instituto Nacional de Pesca, Mexico DF.

[17] Salas, S., Regist, R., Zapata, C., Cabrera, M.A. and Euan-Aavila, J. (2015) How Much We Can Learn from Fishers about Ecology and Fisheries Management: Case Studies on Spiny Lobster Fishery in Mexico. In: Fischer, J., Jorgensen, J., Josupeit, H., Kalikoski, D. and Lucas, C.M., Eds., Fishers' Knowledge and the Ecosystem Approach to Fisheries. Applications, Experiences and Lessons in Latin America. FAO Fisheries and Aquaculture Technical Paper No. 591, Rome, 278.

[18] De Smith, M.J., Goodchild, M.F. and Longley, P. (2007) Geospatial Analysis: A Comprehensive Guide to Principles, Techniques and Software Tools. Troubador Publishing Ltd., Leicester.

[19] Kalman, J. and Liceaga-Correa, M.A. (2009) The Coexistence of Local Knowledge and GPS Technology: Looking for Things in the Water. Maritime Studies, 8, 9-34.

[20] Liceaga-Correa, M.A. and Euan-Avila, J.I. (2002) Assessment of Coral Reef Bathymetric Mapping Using Visible Landsat Thematic Mapper Data. International Journal of Remote Sensing, 23, 3-14. http://dx.doi.org/10.1080/01431160010008573

[21] Quirós, E., Felicísimo, Á.M. and Cuartero, A. (2009) Testing Multivariate Adaptive Regression Splines (MARS) as a Method of Land Cover Classification of TERRA-ASTER Satellite Images. Sensors, 9, 9011-9028. http://dx.doi.org/10.3390/s91109011

[22] Peralta-Meixueiro, M.A. and Vega-Cendejas, M.E. (2011) Spatial and Temporal Structure of Fish Assemblages in a Hyperhaline Coastal System: Ría Lagartos, Mexico. Neotropical Ichthyology, 9, 673-682. http://dx.doi.org/10.1590/S1679-62252011005000033

[23] Huchin-Mian, J.P., Rodríguez-Canul, R., Briones-Fourzán, P. and Lozano-Álvarez, E. (2013) Panulirus argus Virus 1 (PaV1) Infection Prevalence and Risk Factors in a Mexican Lobster Fishery Employing Casitas. Diseases of Aquatic Organisms, 107, 87-97. http://dx.doi.org/10.3354/dao02676

[24] Moss, B. and Allam, B. (2006) Fluorometric Measurement of Oxidative Burst in Lobster Hemocytes and Inhibiting Effect of Pathogenic Bacteria and Hypoxia. Journal of Shellfish Research, 25, 1051-1057. http://dx.doi.org/10.2983/0730-8000(2006)25[1051:FMOOBI]2.0.CO;2

[25] Montgomery-Fullerton, M.M., Cooper, R.A., Kauffman, K.M., Shields, J.D. and Ratzlaff, R.E. (2007) Detection of Panulirus argus Virus 1 in Caribbean Spiny Lobsters. Diseases of Aquatic Organisms, 76, 1-6. http://dx.doi.org/10.3354/dao076001

[26] Huchin-Mian, J.P., Briones-Fourzán, P., Simá-Alvarez, R., Cruz-Quintana, Y., Pérez-Vega, J.A., Lozano-Alvarez, E., Pascual-Jiménez, C. and Rodríguez-Canul, R. (2009) Detection of Panulirus argus Virus 1 (PaV1) in Exported Frozen Tails of Subadult-Adult Caribbean Spiny Lobsters Panulirus argus. Diseases of Aquatic Organisms, 86, 159-162. http://dx.doi.org/10.3354/dao02117

[27] Tamura, K., Dudley, J., Nei, M. and Kumar, S. (2007) MEGA4: Molecular Evolutionary Genetics Analysis (MEGA) Software Version 4.0. Molecular Biology and Evolution, 24, 1596-1599. http://dx.doi.org/10.1093/molbev/msm092

[28] Bush, A.O., Lafferty, K.D., Lotz, J.M. and Shostak, A.W. (1997) Parasitology Meets Ecology on Its Own Terms: Margolis et al. Revisited. Journal of Parasitology, 83, 575-583. http://dx.doi.org/10.2307/3284227

[29] Conover, W.J. (1999) Practical Nonparametric Statistics. John Wiley \& Sons Inc., New York.

[30] Enríquez, S. and Pantoja-Reyes, N.I. (2005) Form-Function Analysis of the Effect of Canopy Morphology on Leaf Self-Shading in the Seagrass Thalassia testudinum. Oecologia, 145, 235-243. http://dx.doi.org/10.1007/s00442-005-0111-7

[31] Behringer, D.C. and Butler, M.J.I. (2010) Disease Avoidance Influences Shelter Use and Predation in Caribbean Spiny Lobster. Behavioral Ecology and Sociobiology, 64, 747-755. http://dx.doi.org/10.1007/s00265-009-0892-5

[32] Behringer, D.C., Butler, M.J.I., Moss, J. and Shields, J.D. (2012) PaV1 Infection in the Florida Spiny Lobster (Panulirus argus) Fishery and Its Effects on Trap Function and Disease Transmission. Canadian Journal of Fisheries and Aquatic Sciences, 144, 136-144. http://dx.doi.org/10.1139/f2011-146

[33] Shields, J.D. (2012) The Impact of Pathogens on Exploited Populations of Decapod Crustaceans. Journal Invertebrate Pathology, 110, 211-224. http://dx.doi.org/10.1016/j.jip.2012.03.011

[34] Kough, A.S., Paris, C.B., Behringer, D.C. and Butler, M.J.I. (2014) Pathogens: The Case of PaV1 in the Caribbean. ICES Journal of Marine Science, 10, 1-8.

[35] Briones-Fourzán, P., Candia-Zulbarán, R.I., Negrete-Soto, F., Barradas-Ortiz, C., Huchin-Mian, J.P. and LozanoÁlvarez, E. (2012) Influence of Local Habitat Features on Disease Avoidance by Caribbean Spiny Lobsters in a CasitaEnhanced Bay. Diseases of Aquatic Organisms, 100, 135-148. http://dx.doi.org/10.3354/dao02465 
[36] Dolan, T.W., Butler, M.J. and Shields, J. (2014) Host Behavior Alters Spiny Lobster—Viral Disease Dynamics: A Simulation Study. Ecology, 95, 2346-2361. http://dx.doi.org/10.1890/13-0118.1

[37] Candia-Zulbarán, R.I., Briones-Fourzán, P. and Lozano-Álvarez, E. (2012) Variability in Clinical Prevalence of PaV1 in Caribbean Spiny Lobsters Occupying Commercial Casitas over a Large Bay in Mexico. Diseases of Aquatic Organisms, 100, 125-133. http://dx.doi.org/10.3354/dao02452

[38] Lu, C.Y., Gu, W., Dai, A.H. and Wei, H.Y. (2012) Assessing Habitat Suitability Based on Geographic Information System (GIS) and Fuzzy: A Case Study of Schisandra sphenanthera Rehd. et Wils. in Qinling Mountains, China. Ecological Modelling, 242, 105-115. http://dx.doi.org/10.1016/j.ecolmodel.2012.06.002

[39] Byamukama, E., Eggenberger, S.K., Robertson, A.E. and Nutter, F.W. (2014) Geospatial and Temporal Analyses of Bean Pod Mottle Virus Epidemics in Soybean at Three Spatial Scales. Phytopathology, 104, 365-378. http://dx.doi.org/10.1094/PHYTO-12-12-0323-R

[40] Meentemeyer, R.K. and Haas, S.E. (2012) Landscape Epidemiology of Emerging Infectious Diseases in Natural and Human-Altered Ecosystems. Annual Review of Phytopathology, 50, 379-402. http://dx.doi.org/10.1146/annurev-phyto-081211-172938

\section{Submit or recommend next manuscript to SCIRP and we will provide best service for you:}

Accepting pre-submission inquiries through Email, Facebook, Linkedin, Twitter, etc A wide selection of journals (inclusive of 9 subjects, more than 200 journals)

Providing a 24-hour high-quality service

User-friendly online submission system

Fair and swift peer-review system

Efficient typesetting and proofreading procedure

Display of the result of downloads and visits, as well as the number of cited articles

Maximum dissemination of your research work

Submit your manuscript at: http://papersubmission.scirp.org/ 